\title{
Death-feigning as defensive behaviour of eight lizard species of the Amazon rainforest
}

\section{CARLOS EDUARDO COSTA-CAMPOS* \& JÉSSICA STEFANY COSTA ANAISSI}

\author{
Laboratório de Herpetologia, Departamento de Ciências Biológicas e da Saúde, Universidade Federal do Amapá, Campus \\ Marco Zero do Equador, 68903-419, Macapá, Amapá, Brazil \\ *Corresponding author e-mail: dududueducampos@gmail.com
}

$\mathrm{D}$ eath-feigning or thanatosis is a defensive behaviour in which an animal adopts a posture resembling a dead individual when it is physically threatened by a potential predator (Hamphreys \& Ruxton, 2018). This can be an effective mechanism against predators that will not feed on dead animals or need to detect prey by its movement (Toledo et al., 2011). The evolution of anti-predatory behaviours is an important component of the natural history of lizards (Downes \& Hoefer, 2004), although until now thanatosis had only been reported for Amazonian lizard in the families Gymnophthalmidae and Tropiduridae. In this study we report the death-feigning behaviour displayed by eight lizards species from the Brazilian Amazon rainforest (Table 1) and add new records for the families Dactyloidae, Alopoglossidae, Gymnophthalmidae and Sphaerodactylidae.

We undertook fieldwork in a terra firme forest at the Reserva Extrativista Beija-Flor Brilho de Fogo, municipality of Pedra Branca do Amapari, Amapá state, Brazil $\left(0^{\circ} 47^{\prime} 30.6^{\prime \prime} \mathrm{N}\right.$, $\left.51^{\circ} 58^{\prime} 42.1^{\prime \prime} \mathrm{W}\right)$. The area consists of dense forest with large trees and sandy and clay ground being the watershed of the Amapari River (Drummond et al., 2008). The local climate is classed as Equatorial (Am) according to the Köppen-Geiger classification with two well-defined seasons: a dry season occurring between July and September, and a rainy season between December and June (Alvares et al., 2013).

The data presented in this study were collected between July and October 2019. During field surveys of the herpetofauna, we captured eighteen species of lizards during active visual searches (Heyer et al., 1994) during the morning. All lizards were handled carefully during measurements (body size and mass). Of the eighteen species of lizard captured, eight species exhibited thanatosis during handling.

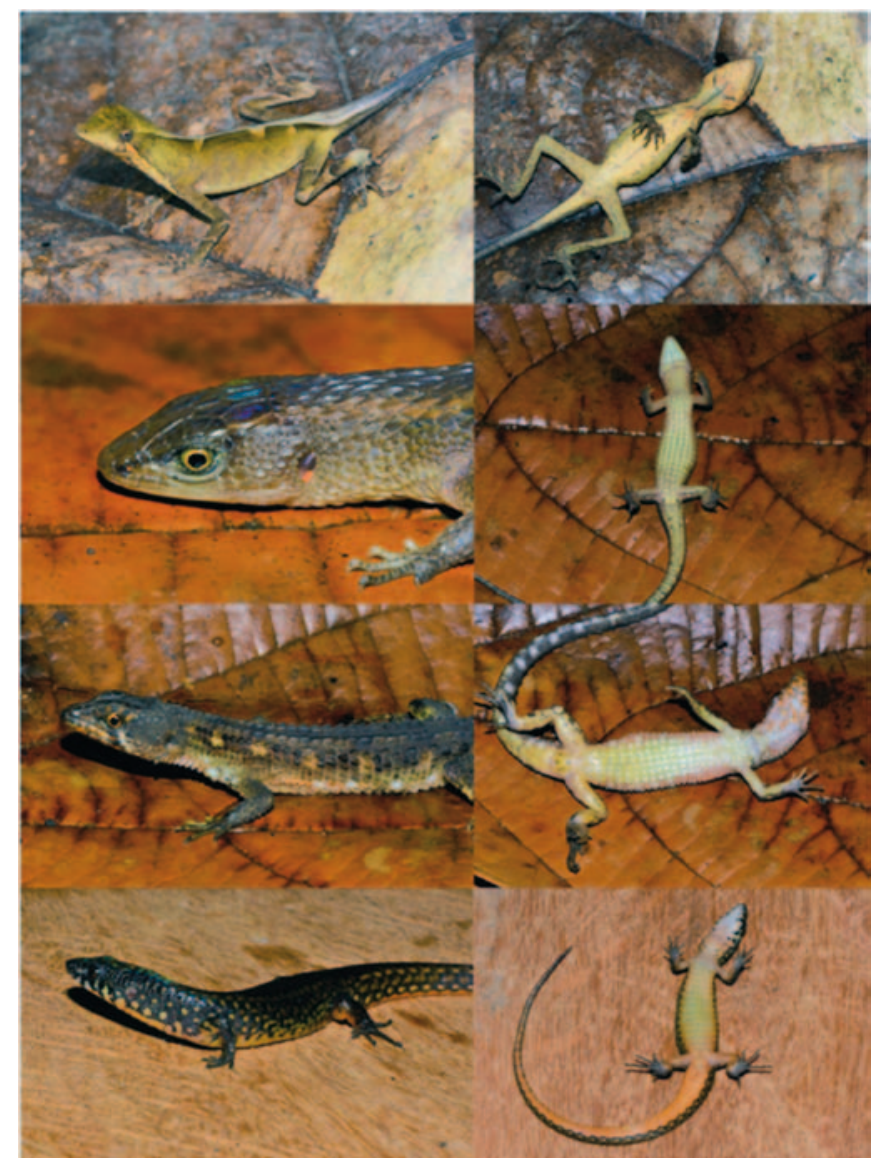

Figure 1. Death-feigning behaviour of Amazonian lizards $N$. chrysolepis, A. angulatus, N. bicarinatus and A. reticulata. (top to bottom)

Table 1. Death-feigning behaviour observed in eight species of Amazonian lizards

\begin{tabular}{|c|c|c|c|c|}
\hline Family & Species & Date in 2019 & Time & Duration of thanatosis \\
\hline Dactyloidae & Norops chrysolepis & 13 July & $13.01 \mathrm{~h}$ & $40 \mathrm{~s}$ \\
\hline Alopoglossidae & Alopoglossus angulatus & 23 October & $08.09 \mathrm{~h}$ & $25 \mathrm{~s}$ \\
\hline \multirow[t]{4}{*}{ Gymnophthalmidae } & Neusticurus bicarinatus & 23 October & $08.13 \mathrm{~h}$ & $50 \mathrm{~s}$ \\
\hline & Arthrosaura reticulata & 24 October & $09.03 \mathrm{~h}$ & $120 \mathrm{~s}$ \\
\hline & A. kockii (male) & 24 October & $09.48 \mathrm{~h}$ & $100 \mathrm{~s}$ \\
\hline & Cercosaura aff. argulus & 25 October & $10.16 \mathrm{~h}$ & $30 \mathrm{~s}$ \\
\hline Sphaerodactylidae & Gonatodes humeralis (female) & 26 October & $09.56 \mathrm{~h}$ & $30 \mathrm{~s}$ \\
\hline Tropiduridae & Plica plica & 26 October & $10.20 \mathrm{~h}$ & $60 s$ \\
\hline
\end{tabular}




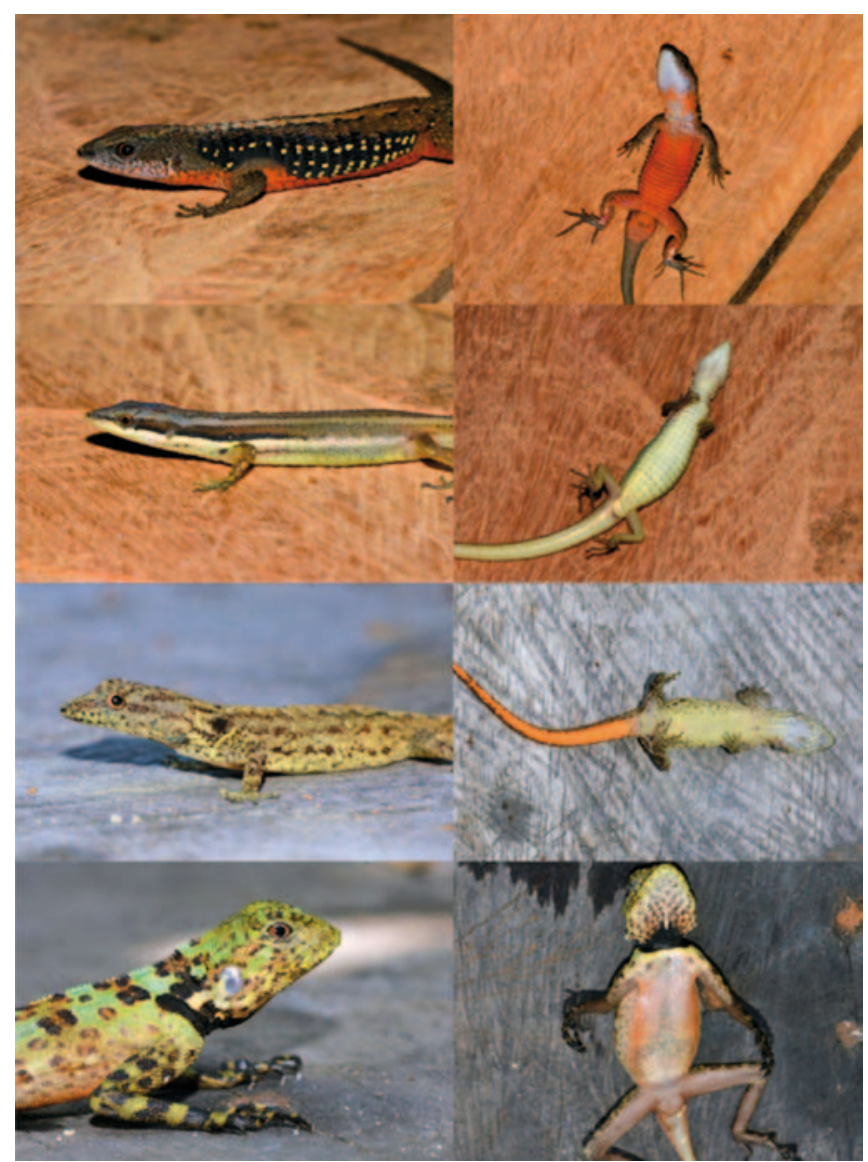

Figure 2. Death-feigning behaviour of Amazonian lizards A. kockii, C. aff. argulus, G. humeralis and P. plica. (top to bottom)

The lizards put themselves in a death-feigning posture by turning their ventral surface upward exposing the cloaca area, contracting the limbs, closing their eyes, and curving their tails laterally (Fig. 1, Fig. 2). This is the first report of death-feigning behaviour of the lizards Norops chrysolepis, Alopoglossus angulatus, Neusticurus bicarinatus, Arthrosaura reticulata, Arthrosaura kockii, Cercosaura aff. argulus and Gonatodes humeralis, and the second record for Plica plica. The specimens collected were deposited in the Herpetological Collection of the Universidade Federal do Amapá, municipality of Macapá, Amapá State, Brazil (CECC).

\section{ACKNOWLEDGEMENTS}

We are grateful to TC Ávila-Pires for the assistance in the lizards identification. We thanks Secretaria Municipal do Meio Ambiente (SEMAM) of Pedra Branca do Amapari for logistical support. Instituto Chico Mendes de Conservação da Biodiversidade (ICMBio/SISBIO \#48102-2) and SEMAM (process \#011/2019) for providing collection permits (\#48102-2).

\section{REFERENCES}

Alvares, C.A., Stape, J.L., Sentelhas, P.C., Gonçalves, J.L.M. \& Sparovek, G. (2013). Köppen's climate classification map for Brazil. Meteorologische Zeitschrift 22: 711-728.

Downes, S. \& Hoefer, A. (2004). Antipredatory behaviour in lizards: Interactions between group size and predation risk. Animal Behaviour 67: 485-492.

Drummond, J.A., Dias, T.C.A.C. \& Brito, D.M.C. (2008). Atlas das Unidades de Conservação do Estado do Amapá. MMA/IBAMA, GEA/SEMA, Macapá, Amapá. 128 pp.

Galdino, C.A.B. \& Pereira, E.G. (2002). Tropidurus nanuzae (NCN). Death feigning. Herpetological Review 33: 54.

Hamphreys, R.K. \& Ruxton, G.D. (2018). A review of thanatosis (death feigning) as an anti-predator behaviour. Behavioral Ecology and Sociobiology 72: Article 22.

Heyer, W.R., Donnelly, M.A., McDiarmid, R.W., Hayek, L.A.C. \& Foster, M.S. (1994). Measuring and monitoring biological diversity: standard methods for amphibians. Washington: Smithsonian Institution Press. 384 pp.

Toledo, L.F., Sazima, I. \& Haddad, C.F.B. (2011). Behavioral defenses of anurans: an overview. Ethology Ecology \& Evolution 23: 1-25.

Accepted: 14 April 2020 